\title{
Komu roste les?
}

\author{
František Všetička \\ (Olomouc, Česká republika)
}

Andrzej Bartyński je další kresovjak, člověk východních kresů. Tam, konkrétně ve Lvově roku 1934, přišel na svět a tam také málem z něho odešel. Za německé okupace se celá rodina zapojila do odboje, on rovněž jako spojka Zemské armády (Armii Krajowej). Jako devítiletého jej gestapo při výslechu připravilo o zrak. Žije a vnímá svět jako nevidomý. $V$ této souvislosti poněkud překvapují názvy jeho sbírek Zelená pohoří (Zielone wzgórza), Komu roste les (Komu rośnie las) nebo Ke chvále slunce (Ku chwale słońca). Bartyński zde nepochybně čerpá z představivosti a fantazie svých raných devíti let.

Poprvé jsem Andrzeje Bartyńského spatřil v Polanicy-Zdroju na básnickém setkání, jež jako předseda vratislavské pobočky spisovatelského svazu vedl. Nejenom je řídil, ale také na něm jako recitátor vystupoval. A právě to mne fascinovalo, nebở zpaměti dovedl zvučným sytým hlasem přednést rozsáhlý text básně.

Tento způsob přednesu nepochybně rovněž ovlivnil charakter a poetiku jeho básnické tvorby. Jde většinou o uvolněný tok slov, který vyjadřuje nějakou situaci či určitý stav. Slova se často opakují a různým způsobem jsou kontaminována, a to často tak dlouho, až je zvolené téma plně vyčerpáno. Jinak řečeno Bartyński netíhne $\mathrm{k}$ básnické zkratce, $\mathrm{v}$ jeho verších se naopak uvolňuje řeka slov a představ, která básnickou zhuštěnost potlačují a nahrazují.

Tento způsob básnické tvorby je blízký zpívané poezii. V této souvislosti třeba dodat, že Bartyński v minulosti prošel pěveckou kariérou, vystupoval jako kabaretiér. Jeho básně a jejich struktura něco takového napovídají. O spjatosti básníkovy poezie s jeho pěveckým projevem dostatečně vypovídá titul jedné jeho sbírky - jmenuje se Kde Ř́m, kde Krym, kde bar Cin-Cin (Gdzie Rzym, gdzie Krym, gdzie bar Cin-Cin). Nikdy jsem nebyl svědkem veřejného pěveckého vystoupení Bartyńského, ale zásluhou Andrzeja Waltera jsem jeho hlas slyšel reprodukován a posléze jsem ho slyšel na 
neveřejném vystoupení. Zpíval jako Pavarotti. Andrzej Walter, jehož poezie svou úsečností př̀dstavuje protiklad Bartyńského básnické tvorby, je zároveň esejista, který se dovede do tohoto způsobu tvorby vcítit, což dokazuje jeho předmluva k Bartyńského sbírce Motýlova hostina (Uczta motyla).

Výše zmíněný titul básnické sbírky proklamuje na prvním místě Rím. Není to záležitost pouze př́ležitostného rýmu, nebot Bartyński ukončil studia na Vratislavské univerzitě magisterskou prací italského zaměření. Šlo o teorii překladu Ř́mských povídek Alberta Moravii. Vedoucím práce byl literární vědec Jan Trzynadlowski, rovněž lvovský rodák. Zůstává mi však do určité míry záhadou, jak mohl nevidomý překládat. Patrně se na tomto úkonu podílel nějaký zprostředkovatel.

V přítomnosti jím je jeho žena Krystyna, Krzysia, která mu je nejen životním druhem, ale především jeho zrakem.

Ř́mské povídky Alberta Moravii otevřely Bartyńskému nejen bránu do akademického světa, ale vnesly do jeho tvorby také vlašský tematický útek. Sbírka Kde Ř́m, kde Krym, kde bar Cin-Cin je cestou po Danteho zemi inspirována. Některé básně vznikly př́mo tam, jiné dlouho po této cestě. Báseň Itálie dodatečně po dvaceti letech jako nostalgická vzpomínka v severní Vratislavi. Báseň začíná:

O Italio stoneczna carissima

Ojczyzno moja bellissima

najdroższa najpiękniejsza

ma Italia najanielsza

najszatańsza złotobiusta pomarańcza

srebrnotona Beatrice

szpada ostra Cosa nostra

Buon giorno Felice

Roma, Siena śmierć jak hiena

Buon giorno Leonardo da Vinci

ty zwyciężasz - tu vinci

$* * * *$

Ó slunečná Itálie carissima

Otčino moje bellissima

nejdražší nejpěknější

má Itálie nejandělštější

nejd'ábelštějši zlatistá pomeranči

stř́brolunná Beatrice

šavle ostrá Cosa nostra

Buon giorno Felice

Roma, Siena smrt jako hyena 
Buon giorno Leonardo da Vinci

ty vítězís - tu vinci

Cítíte ten rozvolněný, melodický, zpěvavý a zpěvácký verš? Ten rozvolněný, rozbíhavý, nesnadno uchopitelný tok mysli? To je Andrzej Bartyński.

Báseň Itálie začíná konstatováním, že tato země je jeho otčinou. V jiných básních Bartyński totéž praví o jiných zemích. V skladbě To jsou otčiny moje (Te są Ojczyzny moje) pak uzavírá, že těchto otcovských zemí je nemalý počet:

\author{
Te sa Ojczyzny moje \\ a jest ich wiele \\ Na greckich łąkach asfodele \\ na Ukrainie mak $i$ chaber \\ a w Niemczech kwitnie koniczyna \\ we Francji chociażby w Paryżu \\ tam żótć wiosenna święto żonkila \\ $w$ Hiszpanii $w$ Czechach albo $w$ Danii \\ może ten kwiatek dla pani? \\ $* * * *$ \\ To jsou otčiny moje \\ a je jich více \\ Na řeckých lukách asfodely \\ na Ukrajině mák a chrpa \\ a v Německu kvete jetel \\ ve Francii třeba $v$ Pařiž $i$ \\ tam jarní žlut' svátkem narcisu \\ ve Španělsku v Čechách nebo v Dánsku \\ může ten kvitek být pro ženy?
}

Moře prostory oceány (Morza przestworza oceany), tak končí báseň. Nevidomému patří celý svět. Andrzej Bartyński dovede jednu ztrátu nahradit mnoha zisky.

\title{
About the author František Všetička \\ Olomouc, Česká republika \\ fvseticka@seznam.cz
}


